\author{
世界の人口長期予測から見たエネルギー需要 \\ （キーワード エネルギー需要予測，世界人口予測，人口增加率とエネルギー消費との関係，エネルギー消費と生活） \\ - 1993.12.10受理一
}

1.はじめに

エネルギーに関する技術開発にとって，その需要お よび供給の予測は技術開発の方向を定めるためには欠 くことができない。しかしながら将来おこるべき社会 あるいは経済の変動を予測し, 確度の高い長期予測を するのは非常に困難である。したがってエネルギー需 要の長期予測は世界的にも高々 50 年先を予測するに止 まっている。しかし，最近のように化石エネルギーの 大量消費か澴境に与える影響を問われるようになると， 従来よりもはるかに長期の予測が必要と考えられるよ うになった。

一方人口については, 世界銀行の予測のように22世 紀におよぶ長期の予測が発表されているので, その予 測との関連においてエネルギーの消費を計ることがで きるようになれば, エネルギー需要の超長期の予測も 可能になると考えられる。

人口の増加と生活水準とは相互に関連することが指 摘されており，ローマクラブがおよそ20年以前に発表 した「成長の限界」にも出生率と一人当り GNPの見 事な関係が示されている ${ }^{1)}$ 。いうまでもなく, GNP は国際的に経済水準を比較することのできる有力な指 標であるが，それが価格変動のあるドルベースである ために，同様の比較を多年度にわたって行うと，バラ ツキが拡大されて奇麗な関係を求められなくなってし まう。筆者はドルのインフレーションを考慮して関係 を求めなおした結果そのバラツキが修正されて, 奇麗 な曲線が描けることを知った。また, 現在の社会が工 ネルギーの消費に支えられて発展していることを考慮 して, 一人当りの GNP あるいはGDP のかわりに, 一人当りのエネルギー消費量を用いて人口増加率との

神戸市灘区高尾通 4丁目 3-15-616(自宅)
元 株式会社神戸製鋼所 森

関係を求めたところ，多年度にわたってかなり奇麗な 関係の得られることを知った。言うまでもなく，世界 の人口は18世紀の産業革命以来急速に増加しはじめ, それと同時にエネルギーの消費も激増していることを 考えれば，むしろ当然の結果と言える。

そこで人口増加率と一人当りのエネルギー消費量と の関係式を求め, 世界銀行の世界人口の長期予測を基 準として世界のエネルギー需要の超長期予測を試みた。 その結果を報告する。

\section{2. 世界の人口増加率と一人当りのエネルギー 消費量との関係}

1973，1976，1983，1986および1989年の世界各国の 人口増加率と一人当りのエネルギー消費量との関係を 図 1 に示した。図 1 では, エネルギー消費量が $2 \sim 4$ TCE に達しているにもかかわらず，人口増加率が 2 〜 3\%である国とエネルギー消費量が $6 \mathrm{TCE}$ を越え るにもかかわらず人口増加率が $1 \%$ を越えるいくつか の国のあることがわかる。この例外の諸国のうちで, 前者は中東が主である産油国であり, 後者は米国, 力 ナダ，オーストラリアなど高い生活水準を保っている が，国土が広くかつ多くの移民を吸収している国であ る。この例外の諸国を除けば，ほとんどの国が図 2 に 示した太い曲線の範囲に含まれることになる。最近急 速な経済成長を遂げ，かつデータの比較的調っている 韓国と日本の経年変動を図上にプロットした。その結 果二三の例外の年を除けば, 二本の太い曲線の内側で, 経済発展につれて右下に移行していることがわかる。 韓国の例外年についてはその原因は明らかではないが, 日本の場合では，例外年はすべて第二次べビーブーム の期間に相当している。日本ではべビーブームの終 わった後は急速に両曲線の中央部に戻り，右下に移行 して行きつつあることがわかる。 


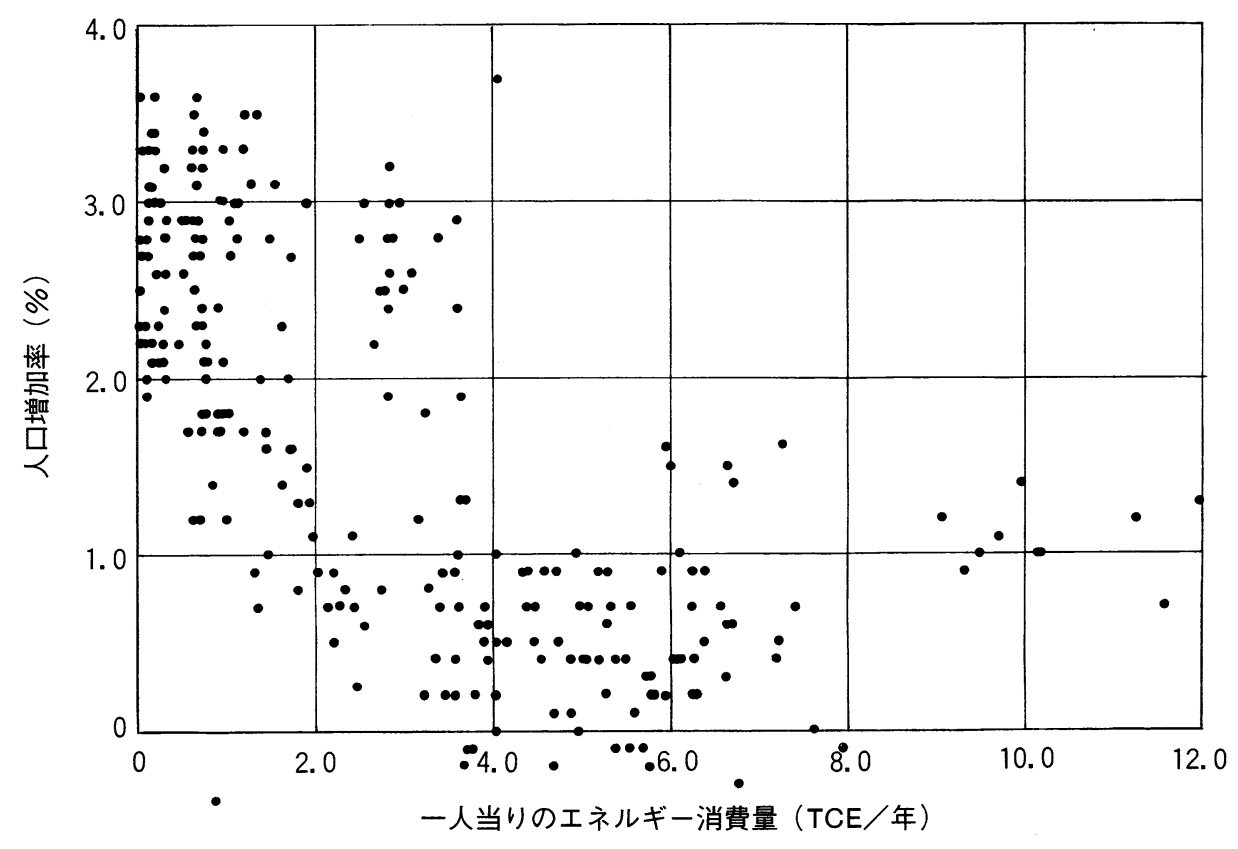

図 1 一人当りのエネルギー消費量と人口増加率の関係

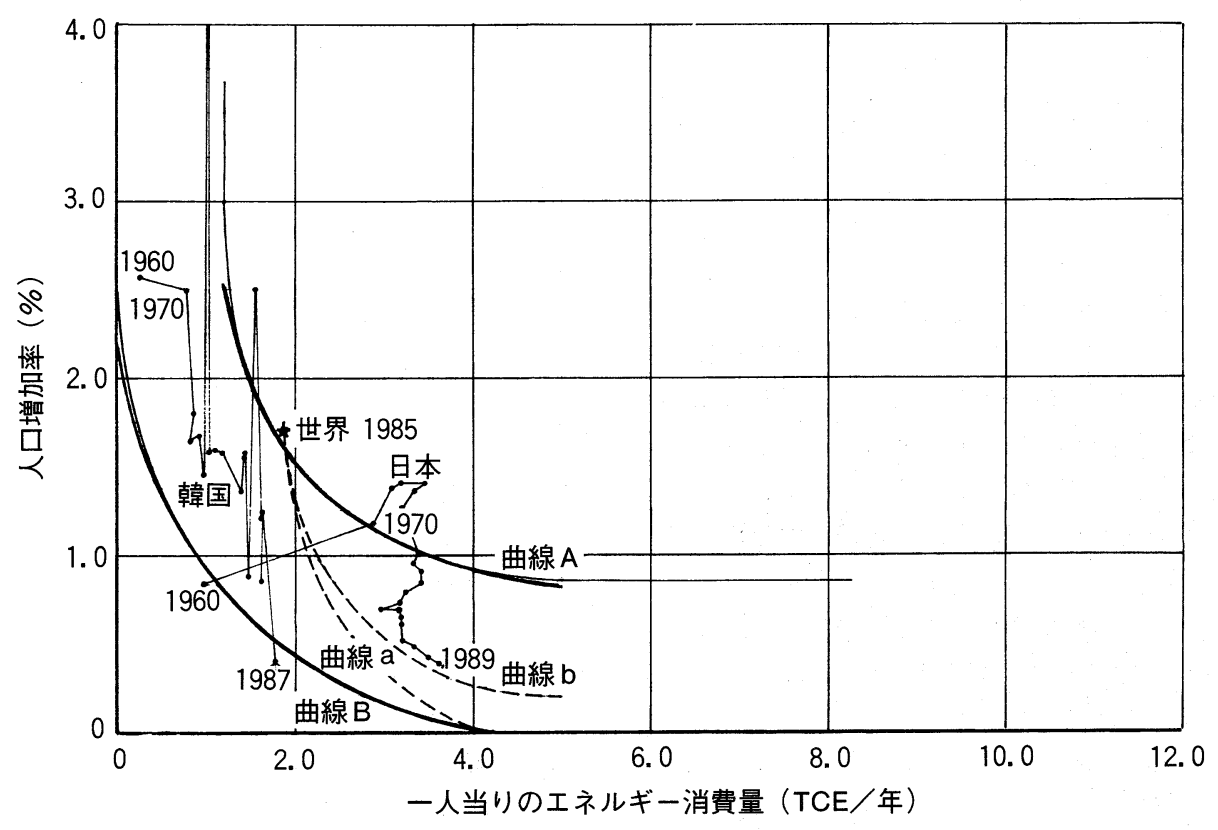

図 2 人口増加率と一人当りのエネルギー消費量の範囲および移行の近似曲線 
この図において分散の範囲を示す二つの曲線は

$\mathrm{Y}=2.7657-\left(-0.2268 \mathrm{X}^{2}+2.3839\right.$

$$
\mathrm{X}-2.4792)^{1 / 2}
$$

$\mathrm{Y}=2.4703-\left(-0.2623 \mathrm{X}^{2}+2.5323\right.$

$$
\mathrm{X}-0.0945)^{1 / 2}
$$

で現される。ここにYは人口増加率, $\mathrm{X}$ は一人当り のエネルギー消費量である。

さきに述べたように，開発途上にある国の人口増加 率と一人当りのエネルギー消費量は, 曲線 $\mathrm{A}$ および $\mathrm{B}$ の間で成長に伴って右下に移行すると考えられ, 先進 諸国は，すでに一人当りのエネルギー消費量の軸に平 行の部分すなわち一人当りのエネルギー消費量が, 年 間 4 TCE から右の部分にある。

1989年現在の世界平均の人口増加率と一人当りのエ

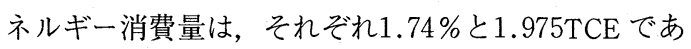
り，ほぼ曲線 Aの上にある。したがって今後は曲線 A およびBの間で右下に移行してゆくものと考えてよい。 その移行の仕方は, 曲線 $\mathrm{A}$ に沿って移行する場合や, 曲線 $\mathrm{a}$ のよう曲線 Aから Bへ移り変わる場合などが 考えられる。また，現在では先進諸国の人口増加率の かなり多くは0.2〜0.3\%であるので，曲線 b のように たとえば人口増加率が $0.2 \%$ 程度で安定してしまう場 合も予想できる。

曲線a およびbはつぎの式によって現される。

$$
\begin{gathered}
\mathrm{Y}=1.8167-\left(-0.4654 \mathrm{X}^{2}+4.2371\right. \\
\mathrm{X}-6.2914)^{1 / 2} \\
\mathrm{Y}=1.9087-\left(-0.341 \mathrm{X}^{2}+3.2374\right. \\
\mathrm{X}-4.7422)^{1 / 2}
\end{gathered}
$$

\section{3. 経年变化}

図 2 は今後㧍こりうる人口増加率と一人当りのエネ ルギー消費量の変化の範囲を示したものであるが, エ ネルギー需要を予測するためには，その経年変化を知 らねばならない。幸い世界銀行では2150年までの世界 の人口の予測が行われており, 近未来を国際連合の予 測で補えば2125年までの人口増加率を推定することが できる。この人口増加率の変化を用いれば, 式 $\mathrm{A}, \mathrm{a}$ および $\mathrm{b}$ を用いてそれぞれの年の一人当りのエネル ギー消費量が算出できる。

表 1 に1990年から 2125 年に到る世界人口, 人口増加 率抢よび式 $\mathrm{A}, \mathrm{a}$ 抢よび $\mathrm{b}$ から算出した一人当りのエ ネルギー消費量および世界のエネルギー需要を示した。 曲線 $\mathrm{A}$ およびbはそれぞれ2019年および2067年までは 人口増加率が世界銀行の人口予測の範囲内であるため にエネルギー需要は算出できるが, 図 3 に示したよう に，その年以後はエネルギー需要が急激に増加するこ

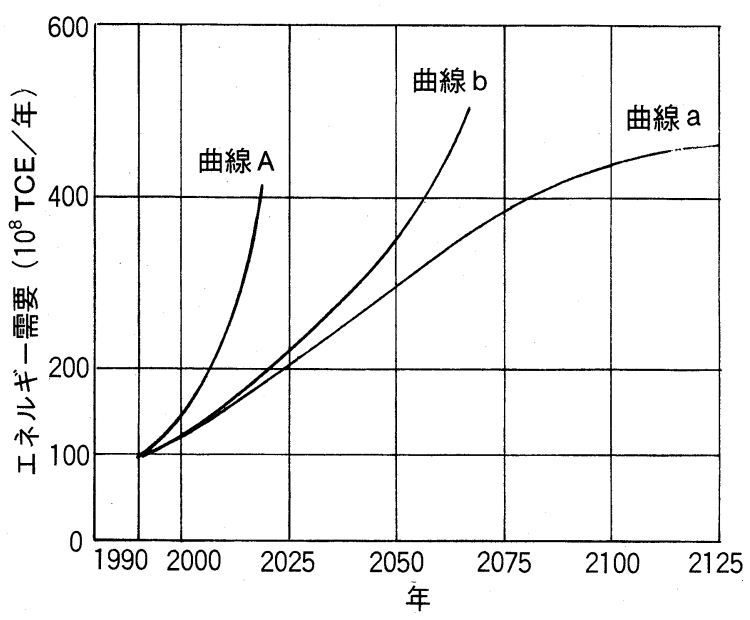

図 3 世界人口予測から推定されるエネルギー需要の ケース

とになり，エネルギー資源とくに化石エネルギー資源 の賦存量から考えるとこれらの曲線に従った変化は考 えにくい。したがって，曲線aのような経路にした がって世界の経済が成長して行かねばならないであろ う。曲線aのような成長をするためには，22世紀まで には人口の増加がほとんどなくなることが必要で，そ のためには人口増加を抑制するなんらかの手段が必要 になろうし，一人当りのエネルギー消費も年間 $4 \mathrm{TCE}$ 程度に止めなければならないと考えられる。

\section{4. 考 察}

人口の増加率と一人当りのエネルギー消費量との関 係を求め, その関係を用いて世界人口の予測值から世 界の総エネルギー消費量を予測する一つの手段を提示 した。

考えてみれば，エネルギーを意欲的に生活の資とし て用いている生物は「ひと」以外にはない。「ひと」 はそのエネルギーを活用して繁栄の道を辿ったのは, とくに大量のエネルギーを動力に転換する方策が開発 された18世紀の産業革命以来人口が爆発的に増加した ことがそれを物語っている。現在では経済成長の指標 としてGNP あるいはGDP が用いられており，その 国際的比較単位としてドルが用いられている。しかし， 各国の通貨をドルに換算するために為替レートを用い なければならないが, 為替レートにはその時点におけ る政治的, 経済的な相互関係の作用することから，

「ひと」の生活の水準を表す絶対的な指標とするには 問題がある。その点, 物理的数值であるエネルギーの 消費量がそれに変わりうるものであれば，はるかに正 確に生活水準を比較できることになろう。そこで，単 
表 1 世界の人口およびエネルギー消費量

\begin{tabular}{|c|c|c|c|c|c|c|c|c|c|c|}
\hline \multirow{2}{*}{$\begin{array}{c}\text { 年 } \\
1900\end{array}$} & \multicolumn{3}{|c|}{ 人 口。(億) } & \multirow{2}{*}{$\begin{array}{c}\begin{array}{c}\text { 人口増加率 } \\
(\%)\end{array} \\
0.77\end{array}$} & \multicolumn{3}{|c|}{$\begin{array}{c}\text { エネルギー消費量 } \\
\left(10^{6} \mathrm{TCE}\right)\end{array}$} & \multicolumn{3}{|c|}{$\begin{array}{c}\text { エネルギー 消 費 量 } \\
\text { (一人当り TCE) }\end{array}$} \\
\hline & $16.2^{1)}$ & & & & $840^{5)}$ & & $1130^{6)}$ & $0.519^{8)}$ & & $0.698^{9)}$ \\
\hline 1910 & 17.5 & & & 0.83 & 1080 & & 1640 & 0.617 & & 0.937 \\
\hline 1920 & 19.0 & & & 0.81 & 1450 & & 1750 & 0.763 & & 0.921 \\
\hline 1930 & 20.6 & & & 0.75 & 2030 & & 2250 & 0.985 & & 1.092 \\
\hline 1940 & 22.2 & & & 1.26 & 2190 & & 2330 & 0.986 & & 1.050 \\
\hline 1950 & \multirow{9}{*}{\multicolumn{3}{|c|}{$\begin{array}{l}25.16^{2)} \\
30.30 \\
33.36 \\
36.98 \\
40.79 \\
44.48 \\
48.51 \\
52.92\end{array}$}} & 1.84 & 2940 & & 3230 & 1.169 & & 1.284 \\
\hline 1960 & & & & 2.01 & 4160 & \multirow{2}{*}{\multicolumn{2}{|c|}{$4233^{7)}$}} & 1.377 & \multirow{2}{*}{\multicolumn{2}{|c|}{$1.402^{7)}$}} \\
\hline 1965 & & & & 2.08 & 5460 & & & 1.637 & & \\
\hline 1970 & & & & 1.98 & 7290 & \multicolumn{2}{|l|}{6821} & 1.971 & \multicolumn{2}{|l|}{1.889} \\
\hline 1975 & & & & 1.75 & & \multicolumn{2}{|l|}{8002} & & \multicolumn{2}{|l|}{2.028} \\
\hline 1980 & & & & 1.75 & & \multicolumn{2}{|l|}{8548} & & \multicolumn{2}{|l|}{1.955} \\
\hline 1985 & & & & 1.76 & & \multicolumn{2}{|l|}{9130} & & \multicolumn{2}{|l|}{1.888} \\
\hline 1990 & & & & & & & & & & \\
\hline 予測 & & & & & & & & & & \\
\hline 1990 & \multirow{2}{*}{\multicolumn{3}{|c|}{$62.50^{3)}$}} & 1.68 & $9873^{10)}$ & $9926^{11)}$ & $9717^{12)}$ & $1.866^{10)}$ & $1.876^{11)}$ & $1.836^{12)}$ \\
\hline 2000 & & & & 1.41 & 14534 & 12095 & 12105 & 2.325 & 1.935 & 1.937 \\
\hline 2010 & \multicolumn{3}{|c|}{71.90} & 1.05 & 23938 & 15206 & 15850 & 3.330 & 2.115 & 2.204 \\
\hline 2025 & & & $84.15^{4)}$ & 0.707 & & 20342 & 22311 & & 2.417 & 2.651 \\
\hline 2050 & & & 100.35 & 0.355 & & 29461 & 35154 & & 2.936 & 3.503 \\
\hline 2075 & & & 109.65 & 0.131 & \multicolumn{3}{|c|}{38429} & \multicolumn{3}{|c|}{3.505} \\
\hline 2100 & & & 113.30 & 0.043 & \multicolumn{3}{|c|}{44036} & \multicolumn{3}{|c|}{3.887} \\
\hline 2125 & & & 114.51 & \multirow[t]{2}{*}{0.017} & \multirow{2}{*}{\multicolumn{3}{|c|}{46481}} & \multirow{2}{*}{\multicolumn{3}{|c|}{4.059}} \\
\hline 2150 & & & 114.99 & & & & & & & \\
\hline
\end{tabular}

1) サイエンス, Vol.10, No.11 (1980), p.28 困から推算

2) Demographic Year Book, Vol.42, (1990), United Nation

3) United Nation の予測 4) World Bank の予測

5) Energy, Global Prospect 1985 2000，(1977), p.17, 図加推算

6 ）世界エネルギー会議コンサベーション委員会, 世界エネルギー2000年を展望して, (1979), 日本動力協会, p.114 図から推算

7）日本統計年鑑，総理府統計局８）1，２，５）放計算

9） 1)，2，，6）加計算 10）曲線 Aを用いて試算

11）曲線 $\mathrm{a}$ を用いて試算 12）曲線 bを用いて試算

年度では密接な関係にある出生率と一人当りの GNP を人口増加率と一人当りのエネルギー消費量の関係に 置き換えたところ，多年度にわたって密接な関係にあ ることが明らかになった。

ある生物種の繁栄は, それを構成する個体数の増加 によって表されるが,「ひと」の場合には人口であり, 産業革命以来の「ひと」の繁栄は, 急激な人口増加が それを表している。しかしながら，国連あるいは世界 銀行の予測によれば, 今後人口の増加は次第に減速し, 22世紀ころにはほとんど平衡に達することが予測され ている。これは，いまや量的な「ひと」の繁栄に関す る $\mathrm{S}$ 字曲線の変曲点にあり,「ひと」が個体数の増加
という繁栄の構造から転換してゆくことを意味してい る。したがって, 今後「ひと」は量的な成長に期待す るよりは質的な繁栄の維持に努めなければならなくな るであろう。それは，わずかに一人当りのエネルギー 消費量の増加という形で質的繁栄の維持が行われるこ とになろう。

一方，「ひと」のエネルギー消費はその大部分を化 石エネルギー資源の消耗に頼っており，この消費パ ターンが続くかぎり, 近い将来にその利用限界に達す ることは「成長の限界」)の指摘に待たず明らかであ る。その限界に到るまでの道筋を出来るだけ正確に予 測し，技術的にも政治・経済的にもその対策を立てる 


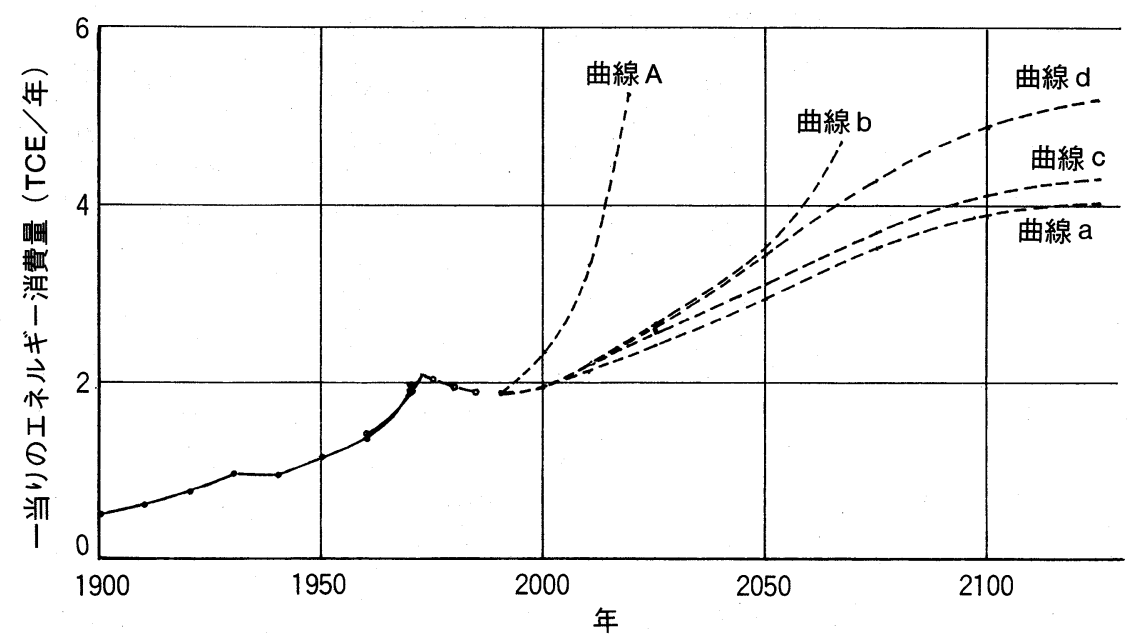

図 4 世界平均一人当りのエネルギー消費量の経年変化とその予測

ことは, 現在の「ひと」の最大の課題であるといって も過言ではない。技術面よりも政治・経済面での対策 の遅れが懸念される。

さらに, 最近大きい関心の持たれているとくに化石 エネルギー資源の大量消費による環境への二酸化炭素 の影響を把握するためにも，正しくエネルギー消費を 予測することは欠くことができない。そのためには極 めて長期の予測を必要とするが, 現在のエネルギー消 費のパターンを延長して予測するには限界がある。し たがって, 数世代にわたり予測可能な人口との関係に おいてエネルギーの消費を予測することができれば, 予測の精度は一層高まると考えられる。この度提示し たエネルギー需要予測の手法は, そのような考え方に 基づいている。

図 2 に示したように，人口の増加から導き出される エネルギー消費が, 現在の消費パターンを続ける限り

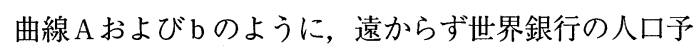
測から逸脱してしまう。したがって，人口予測では22 世紀の前半ではあるが，図 2 における曲線a のように 人口増加率がほぼ 0 になるような経路を辿らねばなら ない。人口増加率が 0 になる一人当りのエネルギー消 費量は，曲線a のように拉よそ4.5TCEであっても， 7 TCE であっても理屈からすれば差し支えないであ ろう。しかし, 現在の世界各国のエネルギー消費パ ターンからみれば, 例外の数ケ国を除いては, ほぼ 4 TCE から $6 \mathrm{TCE}$ 程度で増加か浢打ちになっていると ころから, その程度の消費量を目標にすることが順当 と考えられる。

人口増加率が 0 に達する時の一人当りのエネルギー
消費量を， 5 および 6 TCE として求めた人口増加率 と一人当りのエネルギー消費量の関係式をつぎに示し た。また，比較のために曲線 aをふたたび掲げた。

$$
\begin{gathered}
\mathrm{Y}=2.0896-\left(-0.5164 \mathrm{X}^{2}+4.9092\right. \\
\mathrm{X}-7.2702)^{1 / 2} \\
\mathrm{Y}=1.7539-\left(-0.2035 \mathrm{X}^{2}+2.3556\right. \\
\mathrm{X}-3.7300)^{1 / 2} \\
\mathrm{Y}=1.8167-\left(-0.4654 \mathrm{X}^{2}+4.2371\right. \\
\mathrm{X}-6.2914)^{1 / 2}
\end{gathered}
$$

これらの 3 曲線とさきに示した曲線 $\mathrm{A}$ 抢よび $\mathrm{b} の$ 1900年以降の一人当りのエネルギー消費量（世界平 均）を図 4 に示した。その変化のうち，とくに目立つ のは第二次世界大戦時とオイルショック以来現在まで の消費の伸びの停滞である。現在の停滞が, 第二次世 界大戦時のそれよりも遙かに長期であることは注目し てよい。また，その時期を除くと曲線の曲率はつなが るようで，その延長として曲線 Aがあるように見える。 この二つの停滞の時期がなければ，エネルギー資源の 危機ははるかに早く訪れていたことであろう。曲線 $\mathrm{a}$ から d は, いずれも現在の人口の増加およびエネル ギー消費のパターンが変わらねばならないことを意味 している。それは, 経済成長のかなり大きい減速を意 味するであろう。しかも世界人口予測からみれば，そ の成長は短期間は別としてふたたび増速するとは考え られない。このことは, 技術者のみならず政治家や経 済人をはじめとしてすべての「ひと」が心に留めてお かねばならないように思う。

図 5 にはこれはの曲線から求めた 2125 年までの世界

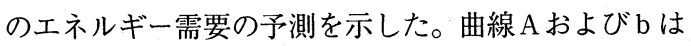




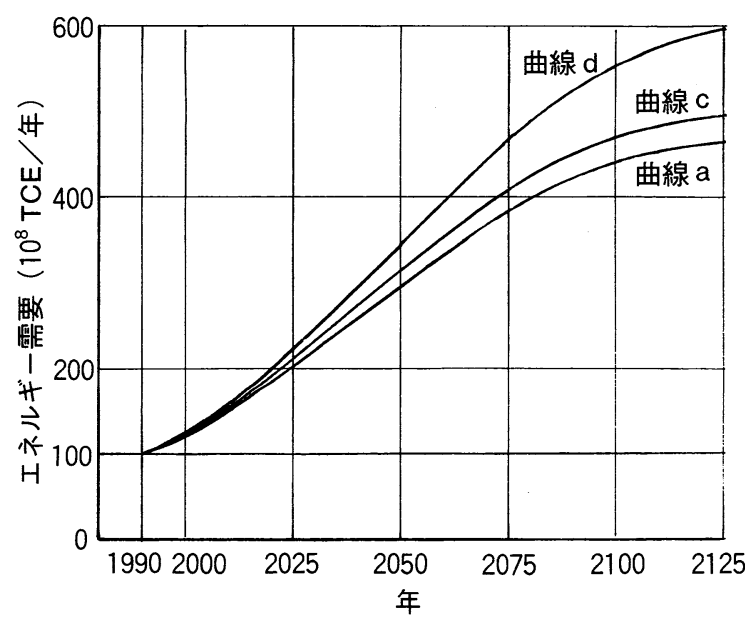

図 5 世界の総エネルギー需要予測

除かれるので，その他の曲線について考えれば，過去 の増加のパターンよりはかなり減速はするものの, 2070年ころまでは，エネルギー消費量の増加すなわち 経済成長は保たれるように思われる。もし，曲線 Aに 沿って成長するとすれば, 現在の経済成長の停帯より もはるかに長期の停滞の時期のあることを予測しなけ ればならないように考えられる。それよりも，むしろ 現在の先進国の人口増加率を考慮した曲線 b に沿って 成長し，2050年ころに再びエネルギー消費パターンの 転換のおこることを考えるほうが現実に近いのかも知 れない。
以上述べたように，世界の人口予測から見たエネル ギー需要予測について考察を進めてきた。しからばそ の予測から，1）今後のエネルギー資源の配分は如何 にあるべきか，2）今後経済成長を続ける過程におい て，その成長の配分は先進国と開発途上国の間でどの ように配分されるべきか，3）そのような世界の変化 に対応して我が国の針路は如何にあるべきか，など多 くの課題か残されている。また，それらの問題を検討 する過程において, さらに多くの課題が生まれてくる ことが予想される。それらの課題については, このエ ネルギー予測を出発点として今後も考察を進めて行き たい。

\section{5.おわりに}

世界人口の長期予測から導かれた世界のエネルギー 需要の長期予測を行った。この予測手法は, 石油学会 の新エネルギー部会の活動の過程でその着想を得た。 この着想を得たことについて，その場を与えて頂いた 石油学会に感謝したい。またこの手法から，それぞれ の地域あるいは国のエネルギー需要予測にも応用する ことができると考えられる。この報告を原点として， 今後も考察を進めて行きたい。

\section{文献}

1) Meadows, D, H., et. al., The Limits to Growth, (1972) (Universe Books)

日本版「成長の限界」大来佐武郎監訳, p.94夕゙ イヤモンド社（昭和47年） 


\title{
World Energy Demand Derived from Long-range Prospect of Population Growth
}

\author{
Kenji MORI \\ (Formerly, Kobe Steel, Ltd.)
}

SYNOPSIS : - It is well known that mean personal energy consumptions and the level of human life have close relation. And also it has been discussed that the rate of population growth changes in accordance with the level of human life. So mean personal energy consumption should have a certain relation with the rate of population growth. It means that the world energy demand should be calculated from the long-range prospect of population growth.

In this article the method to calculate the world energy demand from the long-range prospect of population is described. Fortunately, world population have been prospected till 2150 by the international organization and the prospect of world energy demand derived from population will be calculated till the same period. And the results of calculation will be included automatically a consideration of changes of the level of human life.

By this method the world total energy demand at 2125 is calculated $450 \sim 500 \times 10^{8}$ TCE.

\section{Key Words}

Prospect of energy demand, Prospect of world population, Relation between rate of population growth and mean personal energy consumption, Relation between personal energy consumption and level of human life 